\title{
Az erdőtalaj-képződés ásványtani vonatkozásai a Visegrádi-hegységben, a pilisszentlászlói mintaterületek eruptív anyakőzet összletein
}

\author{
${ }^{1}$ KALMÁR JÁNOS, ${ }^{2}$ IUSTINIAN PETRESCU és ${ }^{3}$ SZENDREINÉ KOREN ESZTER \\ ${ }^{1}$ Magyar Állami Földtani Intézet, Budapest, \\ ${ }^{2}$ Babeş-Bolyai Tudományegyetem, Cluj-Napoca (Románia) és \\ ${ }^{3}$ Erdészeti Tudományos Intézet, Budapest
}

2003 folyamán agrogeológiai vizsgálatokat végeztünk a Duna-Ipoly Nemzeti Park területén, a Visegrádi-hegységben kijelölt két mintaterületen (1. ábra) a vulkáni eredetű kőzeteken kialakult talajok és alapkőzetük közötti kapcsolat megismerése céljából.

A hegyvidéki erdős területeken a talajképződés egy komplex folyamat, amelyben a klimatikus tényezőkön kívül jelentős szerepet játszik a talaj anyakőzetének ásványi összetétele, szerkezete és szövete, valamint a terület morfológiája. A két mintaterület alkalmat ad e tényezők részletes vizsgálatára.

\section{Anyag és módszer}

Kutatásaink a „Természetvédelmi kezelési irányelvek kidolgozását megalapozó vizsgálatok...” címü KAC-pályázati munka keretében folytak (SZENDREINÉ KOREN et al., 2003) az erdészeti szempontok alapján, a térség morfológiai és földtani sajátosságainak ismeretében a Visegrádi-hegység középső részén kiválasztott két mintaterületen (Pilisszentlászló 61A és 65B). A két terület talaj alapkőzet összefüggéseit mintaterületenként $4 \mathrm{db}$ talajszelvény segítségével tártuk fel.

Pilisszentlászló környéke nagy részén badeni korú piroxénes, piroxénesamfibolos és gránátos biotitandezit, kvarcandezit, dácit valamint andezittufa található, amelyek litosztratigráfiailag a Mátrai Andezit Formáció részei. Az eruptív kőzetösszlet földtani megismerését sok természetes és mesterséges feltárás is segíti (LENGYEL, 1951; LÁNG, 1956).

Az itt kibúvó vulkáni összlet egy ún. rétegvulkánnak a része, amelynek a központja körül több másodrendű vulkáni kúp létezett (SZALAI, 1924; WEIN, 1939). Ezekből andezitláva, andezit- és dácit-piroklasztitok kerültek felszínre. A rétegszerü vulkáni kőzettesteket kis méretü andezit és dácit kürtők, tömzsök és telérek szakították át. A vulkáni folyamatokat kísérő gáz- és gőzkitörések hatására egyes kőze-

Postai cím: KALMÁR JÁNOS, Magyar Állami Földtani Intézet, 1143 Budapest, Stefánia út

14.E-mail:kalmarj@mafi.hu 
tekben enyhe ún. hidrotermális elváltozások észlelhetők: agyagosodás, kovásodás, ritkán pirit-, hematit- és limonitlerakódás. A Pilisszentlászló 61A mintaterületen mikrolites amfibolos andezit, a Pilisszentlászló 65B mintaterületen a piroxénesamfibolos andezittufa és agglomerátum rétegszerú képződménye található a felszínen, amelyen számos piroxénes és piroxénes-amfibolos andezittest (telér, lencse, kürtő) hatol át (1. ábra).

Az anyakőzetet fedő, részben talajjellegü laza üledékből mintákat vettünk, amelyeken megvizsgáltuk a szemcseeloszlást, az ásványi összetételt és adott esetben a jelenlevő (fosszilis) pollenasszociációt.

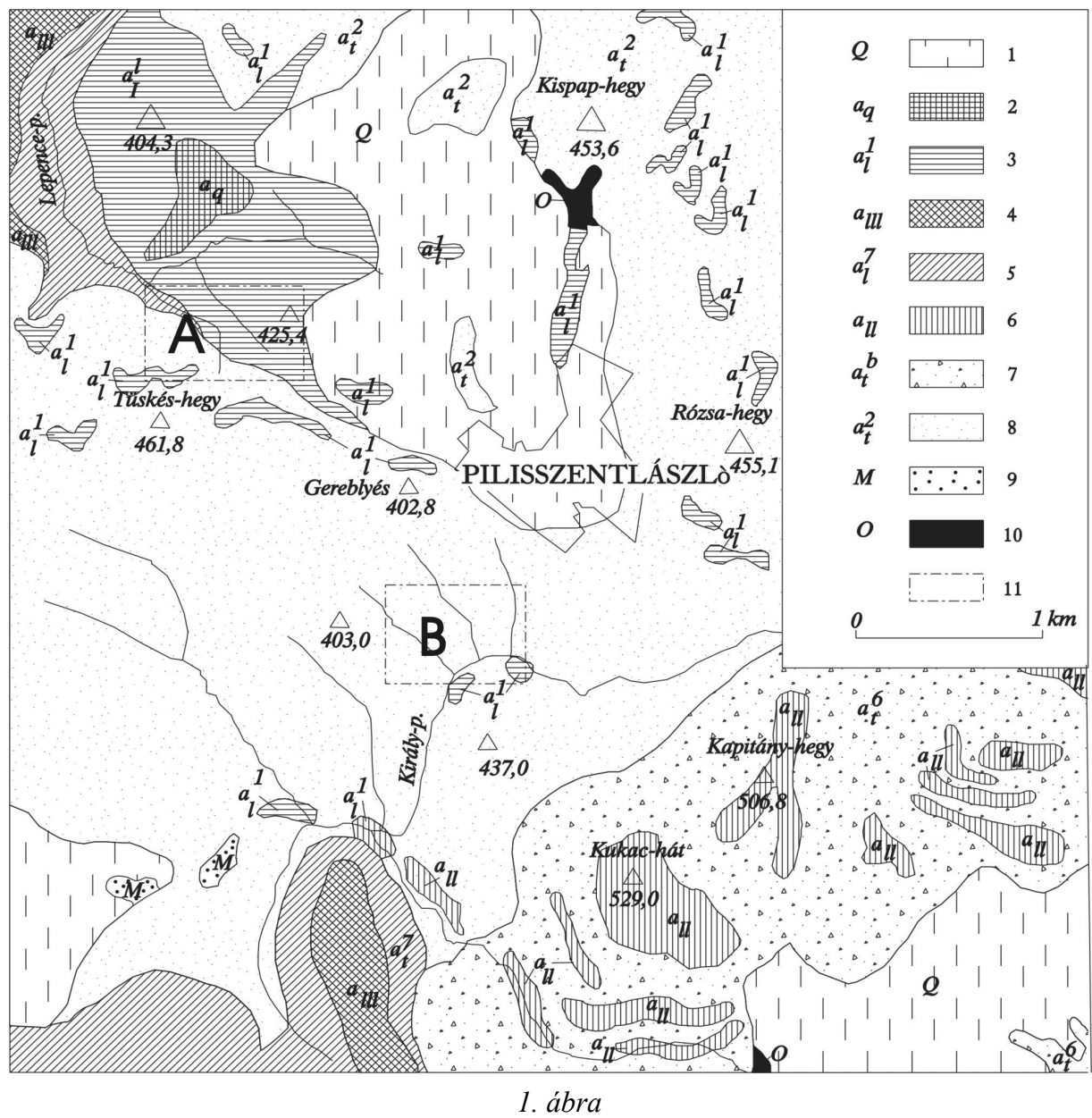

Pilisszentlászló 61A (A) és Pilisszentlászló 65B (B) mintaterület környezetének vázlatos földtani térképe (LÁNG, 1956 adatai alapján). 1. Kvarter: kőzetliszt és homok. 2. Kvarcandezit. 3. Piroxénes amfibolandezet. 4. Gránátos biotitandezit. 5. Gránátos biotitandezit tufa. 6. Biotitandezit. 7. Biotitandezit tufa. 8. Piroxén-amfibolandezit tufa. 9. Miocén Anomiás homok. 10. Oligocén Pectunculusos homok és homokkő. 11. A mintaterületek határa 
A szemcseeloszlást szitálással és a $<0,064 \mathrm{~mm}$ alatti frakciók esetén a szuszpenzió fajsúlymérése alapján állapítottuk meg a MÁFI szediment laboratóriumában; az ásványkőzettani vizsgálatokat a homokfrakciókon Zeiss binokuláris mikroszkóppal, a kőzettöredékeken vékonycsiszolatokon Polmi-A polarizációs mikroszkóppal, a röntgendiffrakciós és termikus vizsgálatokat a MÁFI fázisanalitikai laboratóriumában végezték. A palinológiai vizsgálatok a kolozsvári Babeş-Bolyai Tudományegyetem Környezeti Fakultásának laboratóriumában készültek.

A vizsgálatok célja az volt, hogy kövessük az anyaközet mállási folyamatait a talajásványok kialakulásáig, a finomszemcsés frakció mozgását a talajszelvényen belül és a talaj képződésének időben történő pontosítását. Ezért csak azokból a rétegekből vettünk mintákat, amelyek alkalmasnak látszottak a fent említett feladatok megoldására; így nem került sor a növényi töredékben gazdag vagy túl sok kötörmeléket tartalmazó rétegek megmintázására. Ugyanakkor a nagymüszeres vizsgálatok anyagi vonzatát is figyelembe véve, a fizikai vagy ásványtani szempontból egynemünek tủnő mintákból csak egy-egy került elemzésre.

\section{Eredmények}

\section{A mintaterületek morfológiája}

A Pilisszentlászló 61A mintaterület a Lepence-patak völgye bal oldalán, a Szentendre-Visegrád müúttól nyugatra futó erdei út mindkét felén található, a Lepence-patak bal ágait képező árkok eredeténél (2A. ábra). A SzentendreVisegrád müút bevágása a felszínre hozza a mikrolites amfibolos andezitet, amely az út bal oldalán kb. $50 \mathrm{~m}$ hosszban követhetö. Az út alatt 30-50 m széles sávban a 0,3-0,6 m vastag lejtőtörmelék fejlödik ki, közvetlenül a bontott, agyagosodott andezitre telepedve. A lejtőtörmeléket vörösesszürke színü, agyagos-homokos alapanyagban lévő, gyengén bontott, változatos alakú és nagyságú, szegletes andezittöredék alkotja.

A nyugat felé lejtő völgyoldal hajlatát, amelyen az erdei út halad, lejtölábjellegü üledék fedi, amelynek a vastagsága $1 \mathrm{~m}$ körül van: vörösesbarnás, részben talajosodott kőzetlisztes agyagból vagy homokos agyagból áll, erősen mállott, gyakran görgetett, apró-közepes méretủ andezittörmelékkel és sötétbarna színű, betemetett, lencsés kifejlödésü talajréteggel.

A Pilisszentlászló 65A mintaterület (2B. ábra) a Pilisszentlászlótól délre leágazó erdei úttól DK-re, az út és a Bükkös-patak bal mellékágát képező Király-patak között, két baloldali, sekély árok eredeténél van. A terület általános lejtése DK felé irányul, 3-8 $8^{\circ}$ dőléssel. A területen szálban két andezitkibúvás látható: a műút melletti sziklás területen (3. ábra) és a Király-patak jobb, meredek partján. A terület északi végén, az erdei út mellett és az egyik árok jobb oldalán látható kőmezők, kőtömbök a terület aljzatát képező lazább tufarétegből kiváló, csoportosan szétszóródott andezittömbökböl jöttek létre.

A terület nagy részét az 1,0-1,4 m vastagságú, lencsés-réteges kifejlődésü lejtőláb-üledék fedi, amely az erdei út bal oldalától nyugatra kifejlődő lejtőből szárma- 


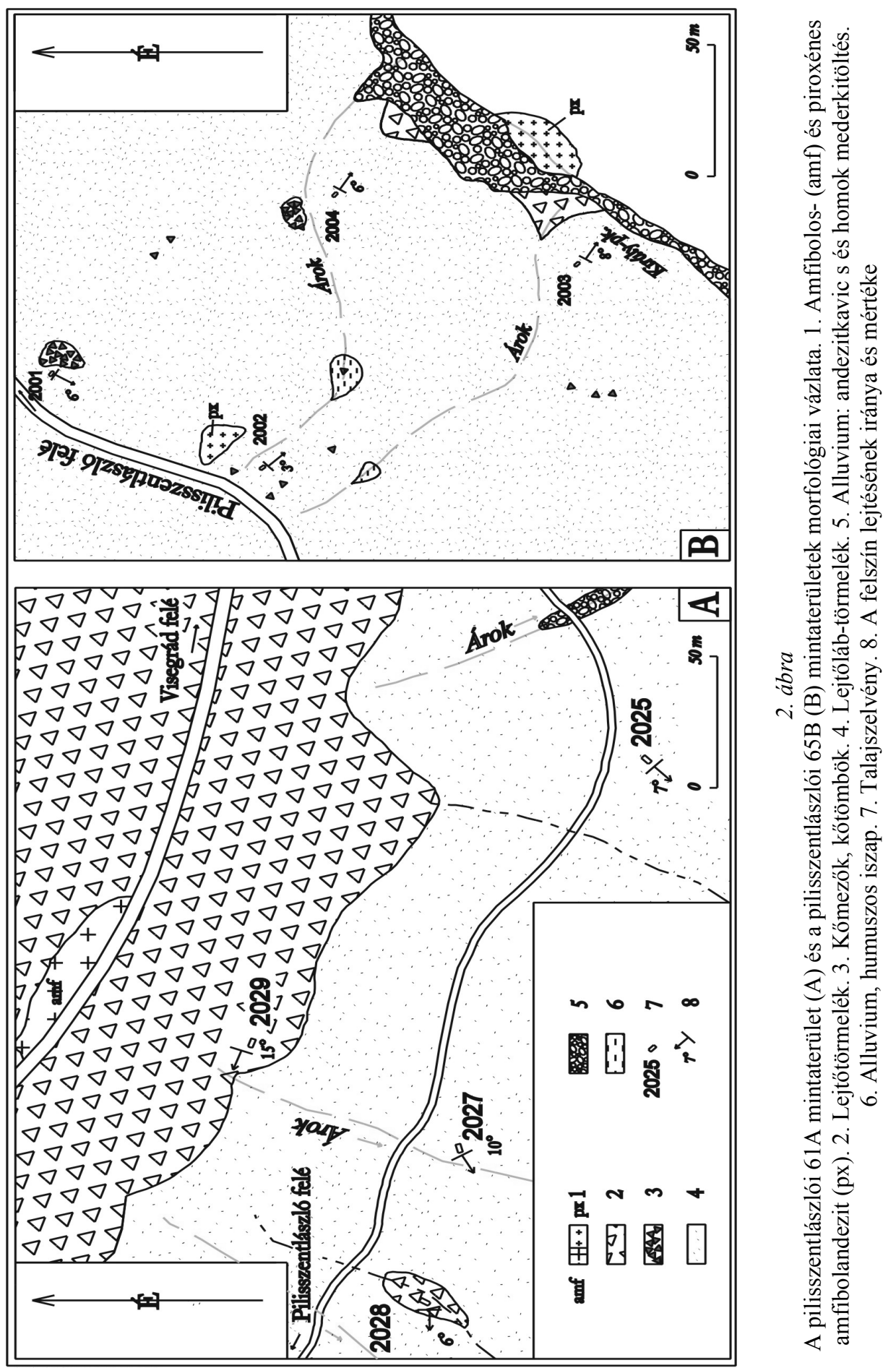




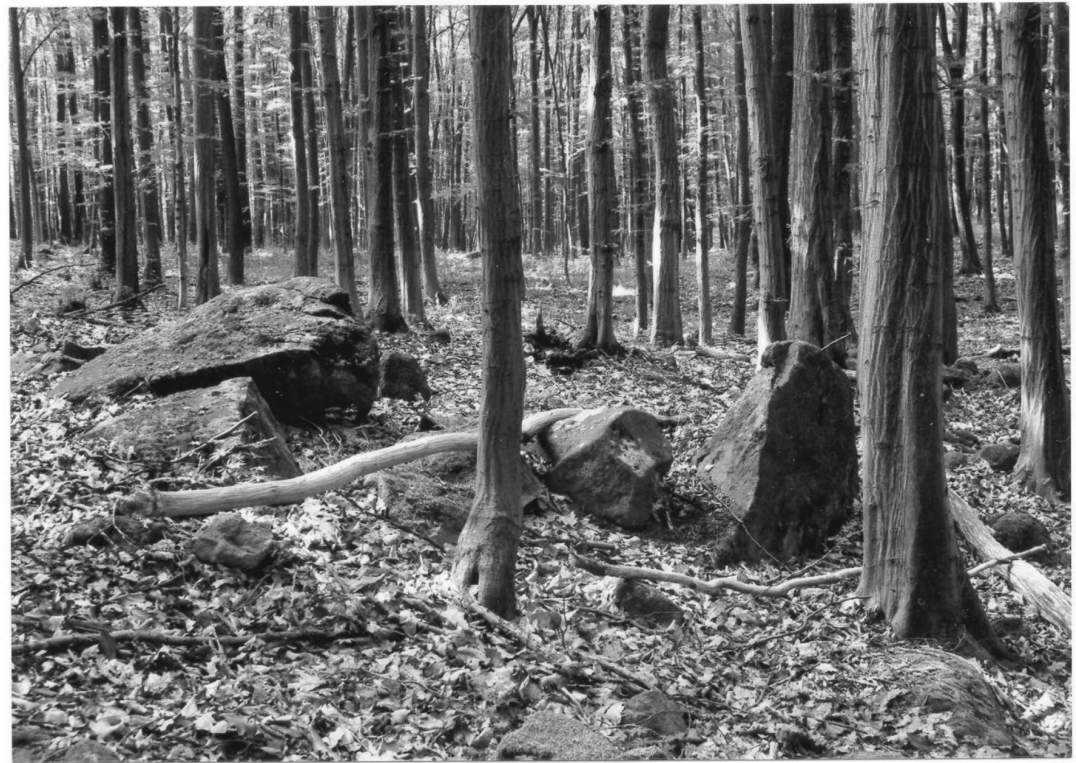

3. ábra

Amfibolos piroxénandezit-szikla (amf) a Szépcseresben, a 2002-es talajszelvény mellett (Fotó: Manninger M.)

zik. Anyaga barnásvörös vagy szürkésbarna homokos vagy agyagos kőzetliszt, esetenként görgetett, enyhén bontott apró-közepes andezit- és horzsaköves tufatörmelékkel, sötétbarna színủ, betemetett talajszintekkel. Két kis sárrét és a Királypatak alluviuma is megjelenik ezen a mintaterületen.

Mindkét területen az aránylag vékony termöréteg heterogén, különböző színü és szemcseösszetételü, 10-20 cm nagyságrendủ lencsékből áll, gyakori, centiméteres görgetett andezitdarabokkal és eltemetett, humuszban gazdag rétegekkel, amelyek a felszín folyamatos eróziójáról és a (kis távolságon mozgatott) anyag lerakódásáról, a talaj színének változásáról és az ezzel járó humusztartalom-csökkenésről (SzŰCS \& SZÜCSNÉ, 2003) tanúskodnak.

\section{A talajok}

A Pilisszentlászló 65B mintaterületen kiválasztott négy kísérleti parcella kitettsége délkeleti, déli és délnyugati, a lejtő hajlásszöge 3-8 közötti. A terület talaja lankásabb felszínü, andezittufán kialakult savanyú barna erdőtalaj, ill. erubáz és savanyú barna erdőtalaj átmenete.

A Pilisszentlászló $61 \mathrm{~A}$ mintaterületen kiválasztott négy kísérleti parcella területének kitettsége északi, a lejtő hajlásszöge $6-15^{\circ}$ közötti, sok esetben meredek.

Talajtípusa, a szelvényleírás és laborvizsgálat alapján podzolos barna erdőtalaj, savanyú barna erdőtalaj, illetve ranker. A talajmintáinkból hiányzik a karbonát és a pH-érték 6 alatt van. 
A felszini-felszín közeli laza üledékek szemcseösszetétele

Az ERTI által leásott 8 szelvényből bemutatjuk három jellegzetes (2025., 2027. és 2003. számú) szelvény rétegsorát (4. ábra).

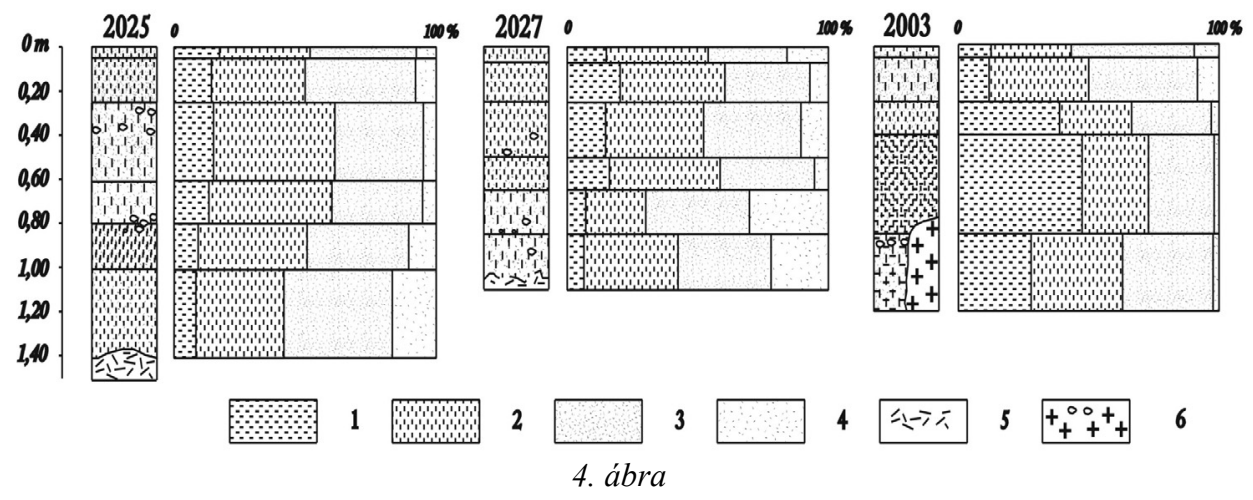

A 2025., 2027. (Pilisszentlászló 61A mintaterület) és 2003. számú (Pilisszentlászló 65B mintaterület) talajszelvények szemcseeloszlása. 1. Agyag $(<0,005 \mathrm{~mm})$. 2. Közetliszt $(0,005-0,06 \mathrm{~mm})$. 3. Finom- és aprószemü homok $(0,06-0,2 \mathrm{~mm})$. 4. Közép- és durvaszemü homok $(0,2-2,0 \mathrm{~mm}) 5$. Bontott andezittörmelék. 6. Piroxénes amfibolandezit, szálba és

kőtömbökben. Megjegyzés: A szelvények helyét lásd a 2. ábrán

A parcella területén feltárt talajszelvények mintáinak egy része homokos kőzetliszt (kőzetlisztes homok), amelyben az agyagfrakció alárendelten szerepel. A minták más része agyagos kőzetliszt (kőzetlisztes agyag), itt a homokfrakció van jelen kisebb mennyiségben. A homokfrakcióban a finomabb szemcséjü homok a domináns. A durvább szemcséjű homok rendszerint a legalsó mintákban, a szilárd kőzetfelszín közelében található nagyobb részarányban.

Fontos megfigyelni az agyag eloszlását a feltárt rétegsorban. Az agyagfrakció részarányának fokozatos növekedése a nyolc szelvényből hétben jól követhető.

\section{A felszíni-felszín közeli laza üledékek ásványi összetétele}

Az felszíni üledék durvaszemcsés frakciója (homok és kavics, ill. törmelék) nagy részét a különböző módon elváltozott, rozsdaszínủ vagy zöldesszürke andezittörmelék (és a Pilisszentlászló 65B mintaterületen jelenlévő nagy mennyiségű horzsakő) képezi. Az üledékben megtalálható a szericitesedett, tejfehér vagy sárgás színezetü, esetenként lekoptatott élü-sarkú hasábokban megjelenő földpát, az opakásványokkal (részben) helyettesített amfibol és piroxén, a szilánkos kvarctöredék és rozsdafoltos, kloritosodott biotitlemezke (1. táblázat). A másodlagos ásványokat kova, limonit és gipsz képviselik.

$\mathrm{Az}$ andezitdarabok mikroszkópos vizsgálata kimutatta, hogy a Pilisszentlászló 61A mintaterületen a kőzet földpátból, opak ásványokkal nagymértékben helyettesített amfibol fenokristályokból, mikrolites, szericitesedett földpátból és kevés kvarcból álló mátrixból tevődik össze. A Pilisszentlászló 65B mintaterületen az andezit- 


\section{1. táblázat}

Homokfrakciók ásványi összetétele (\%-ban) a Pilisszentlászló 61A és 65B mintaterületeken feltárt talajszelvényekből származó mintákban

\begin{tabular}{|c|c|c|c|c|c|c|c|c|c|c|c|c|c|c|c|c|}
\hline \multirow[b]{2}{*}{ 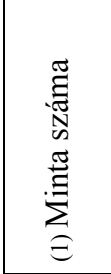 } & \multirow[b]{2}{*}{ 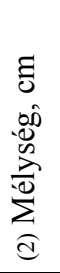 } & \multicolumn{14}{|c|}{ (3) Ásványok } & \multirow[b]{2}{*}{ 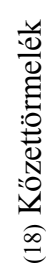 } \\
\hline & & 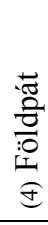 & 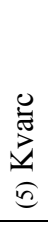 & 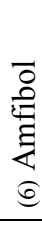 & 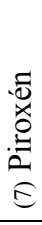 & 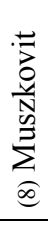 & 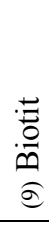 & 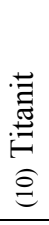 & 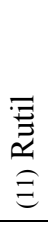 & 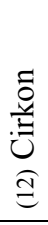 & 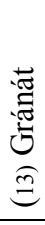 & 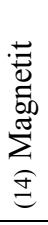 & 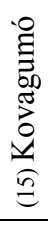 & 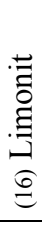 & $\begin{array}{l}N \\
\stackrel{N}{0} \\
\stackrel{0}{E} \\
\stackrel{E}{E}\end{array}$ & \\
\hline $2001 / 3$ & 70 & 22 & 3 & 8 & & $\mathrm{j}$ & $\mathrm{j}$ & 1 & & & & 2 & $\mathrm{j}$ & 4 & & 60 \\
\hline $2002 / 2$ & 35 & 30 & 5 & 10 & & 1 & 1 & $\mathrm{j}$ & $\mathrm{j}$ & & & 1 & 2 & 5 & $\mathrm{j}$ & 45 \\
\hline $2003 / 2$ & 120 & 17 & 10 & 6 & 2 & & $3 *$ & 1 & 1 & $\mathrm{j}$ & & 2 & 3 & 3 & & 52 \\
\hline $2025 / 2$ & 85 & 32 & 5 & 3 & 5 & $\mathrm{j}$ & 3 & 1 & $\mathrm{j}$ & & $\mathrm{j}$ & 3 & 2 & 5 & 1 & 40 \\
\hline $2027 / 2$ & 100 & 18 & 7 & 2 & 2 & 2 & $4^{*}$ & 1 & & & & 4 & 1 & 4 & $\mathrm{j}$ & 55 \\
\hline 2028/1 & 50 & 15 & 5 & 2 & 1 & & $j^{*}$ & $\mathrm{j}$ & 1 & & & 1 & 5 & 5 & & 65 \\
\hline
\end{tabular}

Megjegyzés: j: jelen; *Részben kloritosodott biotit

darabok plagioklászból, piroxénből és üveges-mikrolites mátrixból álló bontott kőzetből állnak. Mindkét területen a színes ásványokból keletkezett klorit és a szericit egy része a láva kihülésekor, autometamorf folyamatok révén keletkezett.

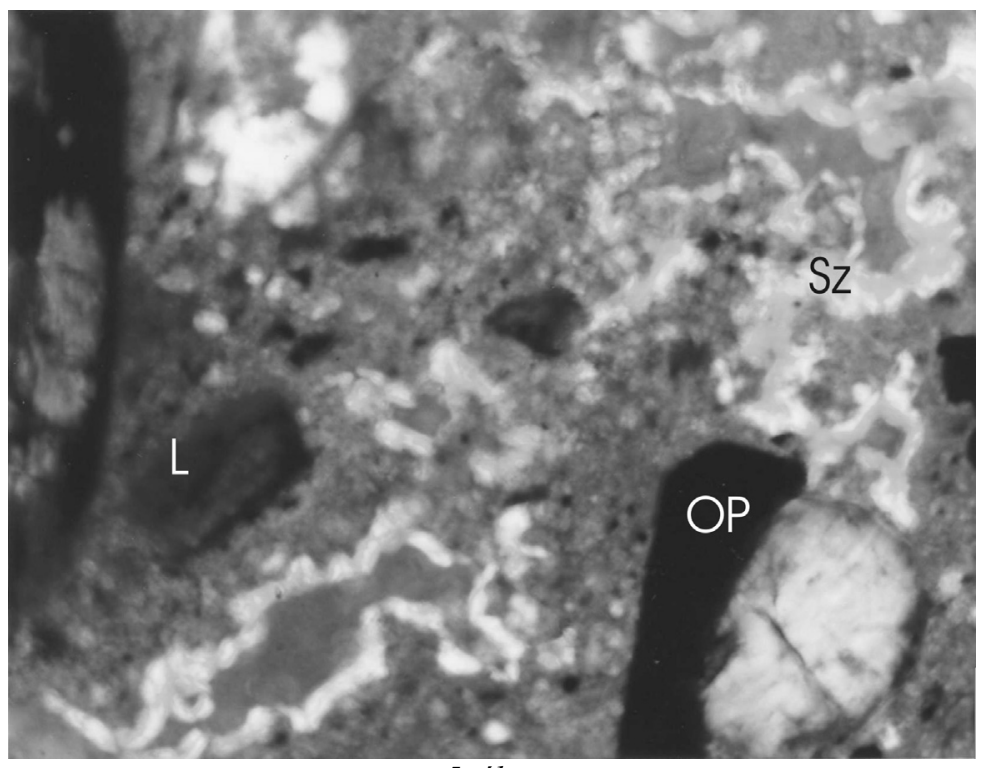

5. ábra

Morzsás (bakteriális?) limonit (sötét, szabálytalan foltok) és élénk színü, redőnyös szmektit-póruskitöltés az amfibolos piroxénandezit-darab málott kérgében. Bal oldalon limonitosodott amfibol-váz; jobbra lent egy piroxén-kristály (Szépcseres, 2004. szelvény, 25 $\mathrm{cm},+$ nikolok, $64 \times$ ) 
Vizsgálataink azt mutatják, hogy a kőzettöredékek felületétől kiindulva fokozatosan gyengülő agyagosodás és limonitosodás észlelhető, valamint a repedések kitöltése kalcedonnal. Ugyanakkor az agyagásványok (valószínüleg vasas montmorillonit), vékony erecskékben behatolnak a kőzetdarabok belsejébe, ahol kitöltik a pórusokat, redőnyös-szalagos halmazokat képeznek. A limonit erekben jelenik meg; az apró gumókból összeálló halmazok nem kizárt, hogy bakteriális eredetủek (5. ábra). Több mintában látható az élénk vörös, izotróp, valószínűleg szerves eredetủ gél behatolása a törmelékek repedéseibe, kioldási üregeibe (6. ábra).

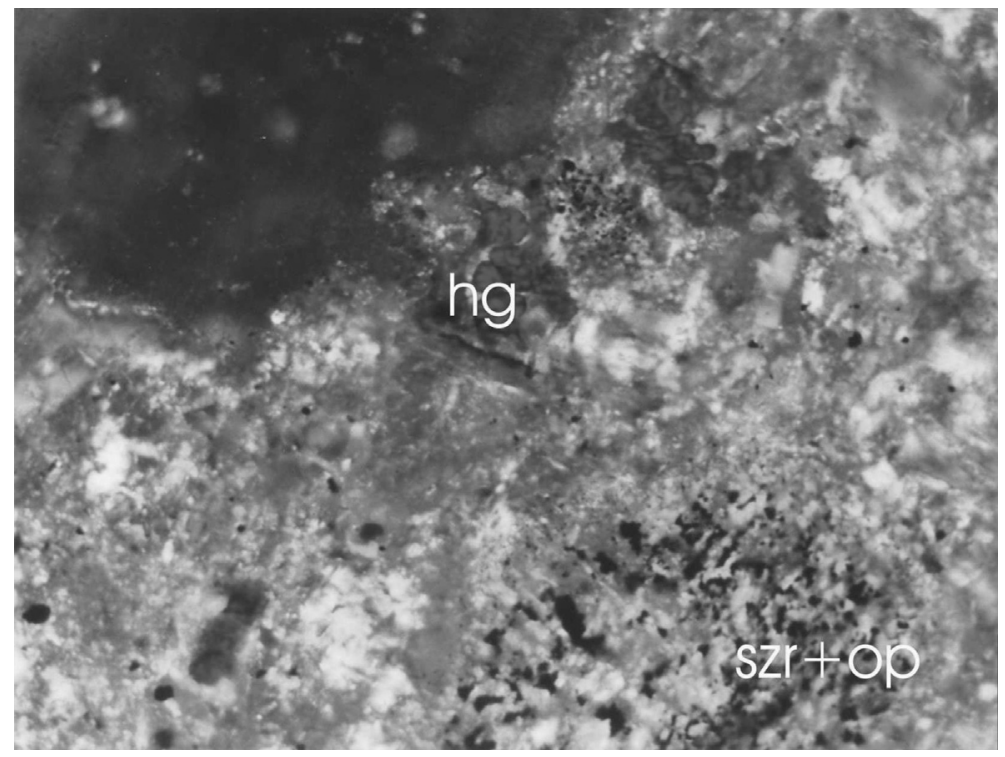

$$
\text { 6. ábra }
$$

Szerves (humuszos?) gél beszüremlés (hg) szericitesedett (szr) és opak ásványokkal (op) impregnált mikrolites amfibolandezitben (2029. szelvény, $60 \mathrm{~cm}$, + nikolok, 64×)

A szilánkos kvarcszemcsék és a muszkovitlemezkék eolikus eredetüek, valószínüleg a közeli lösztakaróból kerültek a termöréteg különböző szintjeibe.

A minták röntgendiffrakciós és termikus vizsgálata kimutatta, hogy a fö agyagásvány a montmorillonit (2. táblázat), kis mennyiségú illittel és illit/szmektit kevertszerkezetủ agyagásvánnyal.

A montmorillonit a mintákban két változatban jelenik meg (7. ábra). A minták nagy részében rendezetlen, gyengén kristályosodott (,pedogenetikus”) montmorillonit van jelen (MEHRING, 1975), így többek között a 2003/1. mintában. Az alapkőzetben viszont a vulkáni tevékenység utóhatása folyamán keletkezett, rendezett, aránylag jól kristályosodott montmorillonit található, a kőzet repedéseiben (pl. a 2028/1. mintában), vagy gömbszerü kiválásokban az üveges mátrixban. Feltételezhető, hogy a termőrétegben a montmorillonit az eruptív anyakőzetben jelenlévő rendezett szerkezetủ szmektitek és a „szericit” (illit?) folyamatos degradációja révén jött létre (MELKERUD, 1985). 


\section{2. táblázat}

A Pilisszentlászló 61A és 65B mintaterületeken feltárt talajszelvényekből származó minták röntgendiffrakciós vizsgálata

\begin{tabular}{|c|c|c|c|c|c|c|c|c|c|c|c|c|c|c|c|c|}
\hline \multirow[b]{2}{*}{ 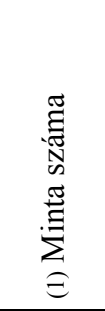 } & \multirow[b]{2}{*}{ 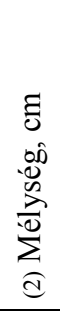 } & \multirow[b]{2}{*}{ 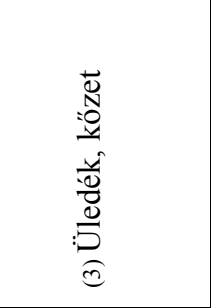 } & \multicolumn{13}{|c|}{ (4) Ásványok, \% } & \\
\hline & & & 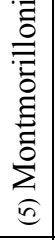 & 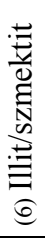 & $\stackrel{: \Xi}{\stackrel{\Xi}{E}}$ & 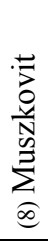 & $\frac{\sqrt{\overrightarrow{0}}}{\stackrel{\overrightarrow{0}}{\hat{\theta}}}$ & 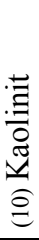 & 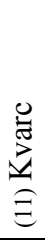 & 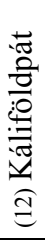 & 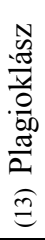 & 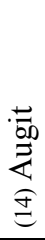 & 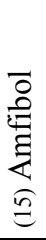 & 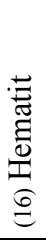 & 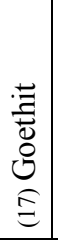 & 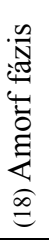 \\
\hline $2001 / 2$ & 35 & a) Közetliszt & 26 & 2 & 7 & 6 & 5 & & 31 & 5 & 14 & ny & 2 & 3 & ny & 5 \\
\hline $2003 / 1$ & 100 & $\begin{array}{l}\text { b) Kőzetlisz- } \\
\text { tes agyag }\end{array}$ & 35 & 4 & 4 & & & 2 & 25 & 2 & 16 & & 2 & 4 & & 7 \\
\hline $2004 / 1$ & 40 & c) Agyag & 36 & 2 & & & & 2 & 25 & 4 & 13 & & 2 & 6 & ny & 6 \\
\hline $2004 / 2$ & 25 & a) Közetliszt & 30 & & & 3 & & & 17 & 5 & 35 & 5 & & & & 5 \\
\hline $2027 / 2$ & 100 & $\begin{array}{l}\text { d) Agyagos } \\
\text { homok }\end{array}$ & 20 & 2 & 6 & & & 1 & 18 & 5 & 12 & & 6 & 4 & 3 & 3 \\
\hline $2028 / 1$ & 50 & $\begin{array}{l}\text { e) Agyagoso- } \\
\text { dott andezit }\end{array}$ & 31 & 3 & 3 & & 1 & & 29 & 6 & 20 & ny & ny & & & 7 \\
\hline
\end{tabular}

Megjegyzés: Az első öt mintánál a teljes üledéket, a 2028/1. mintánál a leválasztott $<0,002$ mm-es frakciót vizsgáltuk meg

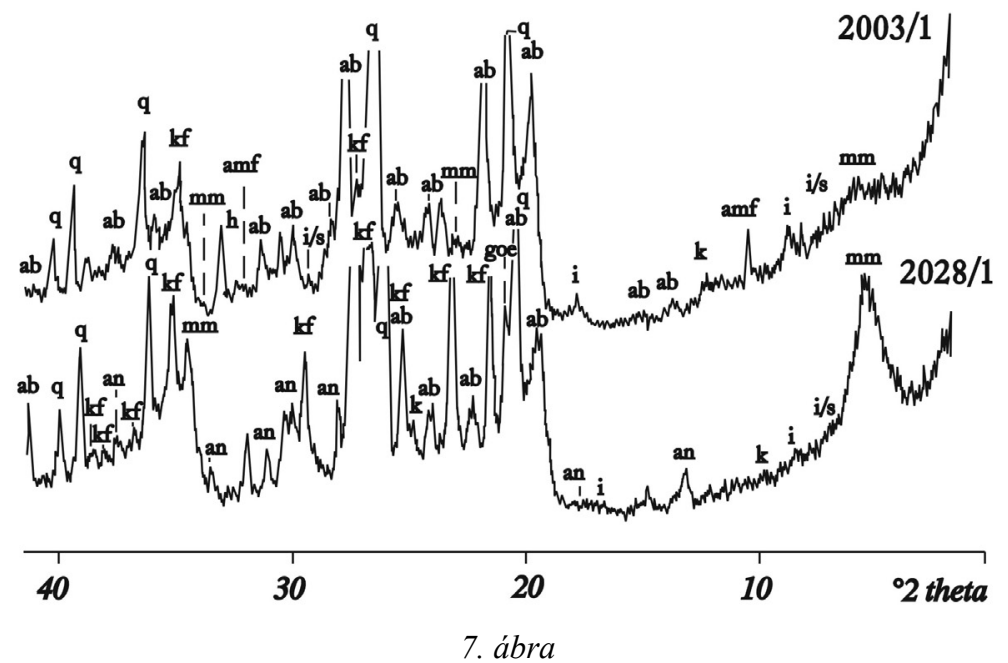

Röntgendiffrakciós diagramok a Pilisszentlászló 61A és 65B mintaterületekröl származó két jellegzetes mintán. A 2028/1. mintán a montmorillonit (mm) bázisreflexiója éles, a 2003/1. mintán egy széles, diffúz, alacsony ívet képez. Egyéb ásványok: ab: albit; amf: amfibol; an: anortit; h: hematit; i: illit; i/s: illit/szmektit kevertszerkezetủ agyagásvány; k: kaolinit+klorit, kf: káliföldpát; q: kvarc 
A mintákban 3-7\%-ban van jelen a röntgenamorf komponens, amely feltehetően a mikroszkóppal is több helyen látható élénkvörös szerves gélből, limonitból és opálból tevődik össze.

\section{Palinológiai és radiometrikus kormeghatározás}

A két mintaterületen az eltemetett talajszintekből vett mintákból a kolozsvári BABEŞ-BOLYAI Egyetem Környezeti Fakultásán pollenanalízist végeztünk (3. táblázat). Az eredmények kiértékelése során figyelembe vettük a Balaton üledékébe mélyült Tó-24 fúráson végezett palinológiai vizsgálatok eredményét is (CSERNY et al., 2001).

A talajszelvények négy eltemetett talajszintet harántoltak. A sötétbarna színü, morzsás-poliéderes vagy leveles elválású, agyagos kőzetliszt-betelepülések lencsés kifejlődésűek, vastagságuk nem haladja meg a $20 \mathrm{~cm}$-t. Alul folyamatosan mennek át a szürke, szürkéssárga vagy szürkésbarna kőzetlisztes-homokos vagy agyagos fekübe. Felfelé a határvonal éles, gyengén hullámos, valószínüleg eróziós felület. Az eltemetett talajszintek nem képeznek tehát egy összefüggő, korrelálható réteget. Pollentartalmuk egyértelmủen a pleisztocént követő felmelegedés optimális fázisába helyezi e rétegeket és ezek alapján lehetséges a szintezésük, a következő módon:

A Pilisszentlászló 61A erdőrészlet 2029. számú kísérleti parcellájának talajszelvénye 40-45 cm közötti mintájában a Corylus pollen kis mennyiségü hidegtürő fák (Pinus, Abies, Picaea, Betula) valamint jelentős mennyiségü, kontinentális sztyeppékre jellemző Artemisiaceae és Chenopodiaceae pollenjával társul. Ez az átmenet a preboreális és boreális fázis között ( $\mathrm{PB} / \mathrm{BO})$, a „mogyoró-kor” elejét jellemzi.

\section{3. táblázat}

A Pilisszentlászló 61A és 65B mintaterületekről származó minták pollenanalízis-eredményei (spóra- és pollenfajok)

\begin{tabular}{|c|c|c|c|}
\hline \multicolumn{4}{|c|}{ (1) Minta száma és származási mélysége, $\mathrm{cm}$} \\
\hline $\begin{array}{l}\text { 2002/3. sz. minta } \\
55-65 \mathrm{~cm}\end{array}$ & $\begin{array}{c}\text { 2003/1. sz. minta } \\
100-110 \mathrm{~cm}\end{array}$ & $\begin{array}{c}\text { 2028/1/1. sz. minta } \\
50-55 \mathrm{~cm}\end{array}$ & $\begin{array}{c}\text { 2029/1/2. sz. minta } \\
40-45 \mathrm{~cm}\end{array}$ \\
\hline $\begin{array}{l}\text { Phytoplancton } \\
\text { Selaginella } \\
\text { Pinus sg. diploxylon } \\
\text { Alnus } \\
\text { Fagus } \\
\text { Carpinus } \\
\text { Polypodiaceae }\end{array}$ & $\begin{array}{l}\text { Pinus sg. diploxylon } \\
\text { Alnus } \\
\text { Fagus } \\
\text { Carpinus } \\
\text { Corylus } \\
\text { Quercus } \\
\text { Polypodiaceae I } \\
\text { Polypodiaceae II }\end{array}$ & $\begin{array}{l}\text { Selaginella } \\
\text { Pinus diploxylon } \\
\text { Picaea } \\
\text { Tilia } \\
\text { Alnus } \\
\text { Fagus } \\
\text { Quercus } \\
\text { Ulmus } \\
\text { Carpinus } \\
\text { Corylus } \\
\text { Ephedra } \\
\text { Artemisiaceae } \\
\text { Chenopodiaceae } \\
\text { Compositae }\end{array}$ & $\begin{array}{l}\text { Muscineae } \\
\text { Pinus diploxylon } \\
\text { Abies } \\
\text { Picaea } \\
\text { Tilia } \\
\text { Fagus } \\
\text { Betula } \\
\text { Corylus } \\
\text { Chenopodiaceae } \\
\text { Artemisiaceae }\end{array}$ \\
\hline
\end{tabular}


Következik a Pilisszentlászló 61A erdőrészlet 2028. sz. talajszelvényének az 50-55 cm közötti mintája, ahol visszaszorulnak a tülevelüek, $\mathrm{s}$ a mogyoró mellett jelentős a tölgy és a hárs pollenjének részaránya is. Ugyanakkor megmarad a sztyeppék lágyszárú növényzetének a pollenje. E számszerinti és fajokban gazdag asszociáció a Corylus zóna E-szintjére jellemző.

A Pilisszentlászló 65B parcella 2003/1. sz. mintája némileg szegényebb asszociációjában már a tölgyfélék dominálnak, ami a „mogyoró-kor” végét jellemzi: a Corylus-Quercus zóna F- és G-szintjeit (BO/AT átmenet). Ugyanakkor a lágyszárú pollen mindössze két Polypodiaceae-fajra korlátozódik és megjelenik a nedvességkedvelö Alnus is.

Végül a Pilisszentlászló 65B 2002/3. talajszelvényének 55-65cm-es szintjéböl eltünik a mogyoró; helyét a bükk-gyertyán foglalja el, jelentős mennyiségü égerpollennel és fitoplanktonnal, amely egyértelmüen az előbbieknél hűvösebb klímájú, nyirkos környezetre, tócsákkal-lápokkal, gyepes tisztásokkal tarkított erdöre utal, az atlanti fázis Q-F zónája határán.

A Pilisszentlászló 65B 2001. szelvényből (Szépcseres), 35-50 cm mélységből egy fészekben apró faszéntöredékeket találtunk, amelyekből a berlini Humbold Egyetem izotóp laboratóriumában radiokarbon-méréseket végeztettünk. Az eredmény: $8600 \pm 166$ év B.P. az óholocén boreális fázisának, a C palinozónának felel meg, pontosítva a pollenalapú kormeghatározást.

\section{Összefoglalás}

A Visegrádi-hegység területén létesített két mintaterületen, a nyolc talajszelvényben - talajtípusukat tekintve - a déli kitettségben savanyú barna erdőtalajok, ill. erubáz és savanyú barna erdőtalaj átmenete, míg az északi kitettségủ parcellákban podzolos barna erdőtalajok, savanyú barna erdőtalaj és ranker jelenik meg. Itt meg kell jegyezni, hogy az erdő termőrétegét képezö lejtöüledék tulajdonképpen számos, mindössze pár tíz $\mathrm{cm}$ vastag, különbözö összetételü, lencsés kifejlődésü, egymásra települő talajrétegből áll, változó mennyiségü kőzettörmelékkel.

A feltárt talajrétegek komplex vizsgálata során kimutattuk, hogy a talaj vázanyagát alkotó üledék föleg homokos-iszapos (kőzetlisztes) jellegü, nagy mennyiségü törmelékkel, amely a közvetlen alatta fekvő vulkáni közetekből (andezit láva és piroklasztit) származnak. A szemcseeloszlás alapján kimutatható, hogy a szelvények nagy részében létezett egy deszcendens agyagfrakció-dúsulás.

A törmelékszemcsék mikroszkópos vizsgálata kimutatta, hogy az andezit mállása jelenleg is folyamatban van, a talajképződés részeként.

A talaj finom frakciójában megjelenő agyagásványok, így a montmorillonit, az illit és az illit/szmektit kevertszerkezetü ásvány, részben az andezit hidrotermális elváltozása, részben a talajtani folyamatok során keletkeztek. Feltételezhető, hogy a talajban kis mennyiségben megjelenő szilánkos kvarcszemcsék és a muszkovitlemezek eolikus eredetüek.

Az egyes mintákon végzett pollenanalízis alapján megállapítható, hogy a jelenlegi talajszelvény a holocén $\mathrm{PB} / \mathrm{BO}$ átmenettől az AT fázis kevert tölgy pollenszint- 
je között folyamatosan keletkezett. Ez korrelálható az egyik szelvényben talált faszén ${ }^{14} \mathrm{C}$ kormeghatározásával.

Kulcsszavak: Visegrádi-hegység, erdőtalajok, montmorillonit, pollen, ${ }^{14} \mathrm{C}$ kor

\section{Irodalom}

CSERNY T. et al., 1991. A Balaton aljzatában mélyített TÓ 24. sz. fúrás földtani vizsgálatainak eredményei. In: MÁFI Évi Jelentés 1989-ről. 179-239. MÁFI. Budapest.

LÁNG I., 1956. 4962 (1. Szentendre) 1:25000 egységesített térképlap. MÁFI Térképtár. Budapest.

LENGYEL E., 1951. A Dunazug-hegység andezitterületének felépítése. In: MÁFI Évi Jelentése. 17-26. MÁFI. Budapest.

MeLKERUD, P. A., 1985. Smectite formation below stands of $1^{\text {st }}, 2^{\text {nd }}$ and $3^{\text {rd }}$ generation of coniferous forest. In: Proc. Symposium „Clay Minerals in Modern Society”. 133-150. Uppsala .

Merin, J., 1975. Smectites. In: Soil Components. Vol. II. Inorganic Components. (Ed.: GIESEKING, J. E.) 97-119. Springer. Berlin-Heidelberg-New York.

SzALAI T., 1924. Új adatok Pomáz és környékének geológiájához. Földtani Közlöny. 54. (1-2) 104-112.

SZENDREINÉ KOREN E. et al., 2003. Természetvédelmi kezelési irányelvek kidolgozását megalapozó vizsgálatok a Duna-Ipoly Nemzeti Park bükkös és gyertyános-tölgyes klímájában, tekintettel a termőhelyi viszonyokra, a talajok vízgazdálkodási adottságaira, a faállományok fafaj-összetételének alakulására, a biológiai diverzitás megőrzésének bővítésére. I. ERTI. 2-112. Budapest.

SzŰCS M. \& SZÜCS M.-NÉ, 2003. Talajtulajdonságok hosszú idő alatt bekövetkezett változásai a Dunántúlon. Agrokémia és Talajtan. 52. 293-304.

WEIN GY., 1939. Szentendre környékének földtani viszonyai. Földtani Közlöny. 69. (13) 26-46.

Érkezett: 2005. október 19. 


\title{
Mineralogical Aspects of Soil Formation on Igneous Parent Materials, Pilisszentlászló Model Areas (Visegrád Hills, Hungary)
}

\author{
${ }^{1}$ J. KALMÁR, ${ }^{2}$ I. PETRESCU and ${ }^{3}$ E. SZENDREI-KOREN \\ ${ }^{1}$ Hungarian State Geological Institute, Budapest, ${ }^{2}$ Babeş-Bolyai University, Cluj-Napoca \\ (Romania) and ${ }^{3}$ Forest Research Institute, Budapest
}

\begin{abstract}
Summary
Two model areas in the Visegrád Hills, with eight soil profiles were studied: model area No. 65B with a southern exposure and model area No 61A with a northern exposure. The soil types in the $65 \mathrm{~B}$ area were acidic brown forest soil and a transition between erubase and acidic brown forest, while the soils in the 61 A area were podzolic brown forest soil, acidic brown forest soil and ranker soils.

The slope deposits were made up of numerous lens-like levels of different soil types, each only a few decimetres thick, with various amounts of rock fragments.

The grain size of the mineral components in the soil samples varied between sand and silt. The $>2 \mathrm{~mm}$ fragments originate from the underlying andesites and pyroclastites. The particle size distribution indicated the enrichment of the clay fractions with depth.

Microscope analyses of the rock fragments showed that the weathering of the andesite was still in progress and was thus part of the soil-forming processes.

The clay minerals of the fine granulometric fractions (montmorillonite, illite, illite/smectite mixed layers) were formed (i) by the hydrothermal transformation of andesites and pyroclastites and (ii) by soil processes. The differences between endogenic and "pedologic" clay minerals lie in the degree of crystallinity and in the size of the clay mineral sheets.

It is probable, that the small quantities of splintered quartz grains and the muscovite sheets are of Eolian origin.

Palynological analysis was used to determine the age of the present soil. It was established that the various buried soil horizons were formed during the Holocene between the $\mathrm{PB} / \mathrm{BO}$ transition and the mixed oak pollen phase of the AT period. The palynological age correlated well with the radiogenetic ${ }^{14} \mathrm{C}$ age taken from a buried charcoal sample.

Table 1. Mineral composition of the sand fraction (\%) of samples originating from soil profiles in the Pilisszentlászló 61A and 65B model areas. (1) Sample No. (2) Sampling depth, cm. (3) Minerals. (4) Feldspars. (5) Quartz. (6) Amphibole. (7) Pyroxen. (8) Muscovite. (9) Biotin. (10) Titanate. (11) Rutile. (12) Zircon. (13) Granite. (14) Magnetite. (15) Limonite. (17) Gypsum. (18) Rock fragments.

Table 2. X-ray diffraction analysis of samples originating from soil profiles in the Pilisszentlászló 61A and 65B model areas. (1) Sample No. (2) Sampling depth, cm. (3) Sediment, rock. (4) Minerals, \%. (5) Montmorillonite. (6) Illite/smectite. (7) Illite.

(8) Muscovite. (9) Chlorite. (10) Kaolinite. (11) Quartz. (12) Potassium feldspars. (13) Plagioclase. (14) Augite. (15) Amphibole. (16) Hematite. (17) Goethite. (18) Amorphous phase.
\end{abstract}


Table 3. Pollen analysis of samples originating from the Pilisszentlszló 61A and 65B model areas (spore and pollen species). (1) No. of sample and sampling depth, $\mathrm{cm}$.

Fig. 1. Geological sketch of the surroundings of Pilisszentlászló 61A (A) and Pilisszentlászló 65B (B) model areas (after LÁNG, 1956). 1. Quaternary silt and sand. 2. Quartziferous andesite. 3. Amphibolic andesite with pyroxen. 4. Biotitic andesite with garnets. 5. Biotitic andesite tuff with garnets. 6. Biotitic andesite. 7. Biotitic andesite tuff. 8. Pyroxenic-amphibolic andesite tuff. 9. Miocene sand with Anomya. 10. Oligocene sand and sandstone with Pectunculus. 11. Boundaries of the model areas.

Fig. 2. Morphological sketch of Pilisszentlászló 31A (A) and Pilisszentlászló 65B (B) model areas. 1. Outcrops of amphibolic (amf) and amphibolic andesite with pyroxene (px). 2. Slope (deluvial) deposits. 3. Stone fields, insulated blocks. 4. Proluvial deposits. 5. Alluvium: andesite gravels and sand as riverbed filling. 6. Alluvium: humic mud. 7. Soil profiles. 8. Local inclination of the surface, in degrees.

Fig. 3. Pyroxenic andesite rocks with amphibole in Szépcseres, near to soil section No. 2002 (photo: M. Maninger).

Fig. 4. Granulometric distribution of profiles No. 2025 and 2027 (Pilisszentlászló 61A) and 2003 (Pilisszentlászló 65B). 1. Clay $(<0.005 \mathrm{~mm})$. 2. Silt $(0.005-0.06 \mathrm{~mm})$. 3. Fine sand $(0.06-0.2 \mathrm{~mm})$. 4. Medium and coarse sand $(0.2-2.0 \mathrm{~mm})$; 5 . Altered andesite fragments; 6 . Blocks and outcrops of pyroxenic andesite with amphibole. Note: For location of soil profiles see Fig. 2.

Fig. 5. Crumbly (bacterial?) limonite (dark, irregular patches) and freshly coloured, radial, pore filling smectite in pyroxenic andesite with amphibole. Left: a limonitized amphibole skeleton. Bottom right, bottom a pyroxene crystal. Szépcserés, soil profile No. 2004. (0.25 m; + nichols, $64 \times)$

Fig. 6. Infiltration of organic (humic?) gel, in sericitized (szr) and opaque (op) microlitic amphibolic andesite with limonite impregnations. Soil profile No. 2029, 0.60 m. + nichols, $64 \times$

Fig. 7. X-ray diffractometric patterns for two characteristic samples from the Pilisszentlászló model areas 61A and 65B. In sample No. 2028/1, the basal reflection of montmorillonite (mm) is sharp, while in sample No. 2003/1, it forms a large, step arch. Other minerals: ab: albite; amf: amphibole; an: anortite; h: hematite; i: illite, i/s: illite/smectite mixed layer clay mineral; k: kaolinite and chlorite; kf: potassium feldspar; q: quartz. 